\title{
К ВОПРОСУ КЛИНИКИ И ДИАГНОСТИКИ ЭПИЛЕПТИЧЕСКИХ ЭНЦЕФАЛОПАТИЙ
}

\author{
*Н.Н.Абасова, С.П.Алекперова, Н.Д.Исаева
}

Азербайджанский Медиџинский Университет, кафедра неврологии и медиџинской генетики, Баку

$\mathbf{P}$ анний детский возраст характеризуется непрерывным процессом развития структур и функций организма, в особенности центральной нервной системы, которая обеспечивает адаптацию организма ребёнка к условиям внешней среды. Головной мозг человека единственный орган, морфологическое и функциональное развитие которого продолжается и совершенствуется в течение нескольких лет постнатального онтогенеза (Анохин П.К., 1935; Аршавский И.А., 1982; Volpe J., 1987).

Новый подход к исследованию влияния эпилептического процесса на состояние мозга стал возможным с широким внедрением в практику методов ЭЭГ. Отправным моментом стала работа Landau and Kleffner 1957 г., описавшим "приобретенную эпилептическую афазию". В развитии учения об эпилептической энцефалопатии важным этапом явилась публикация марсельской школы исследователей 1971 г., описавших "электрический эпилептический статус, вызванный сном у детей". Все это привело к формулировке совершенного нового понятия эпилептических энцефалопатий.

Концепция эпилептических энцефалопатий основана на предположении, что агрессивная эпилептическая активность в период созревания головного мозга является главным причинным фактором когнитивного и нейропсихологического ухудшения или регресса. Эта разрушительная эпилептическая активность является возрастзависимой реакцией на различные патологические состояния, которые могут быть диффузными, фокальными, идиопатическими и симптоматическими. Данная эпилептогенная реакция присуща именно незрелому мозгу и ее выраженность в значительной степени зависит от стадии созревания на время дебюта заболевания.

Так, например, клинические проявления приступов у новорожденных значительно отличаются от симптомов у более старших детей *e-mail: nailya43@rambler.ru и взрослых. У младенцев не бывает организованной генерализованной эпилептиформной активности, не встречаются генерализованные тонико-клонические приступы и абсансы (T.Browne,G.Holmes,2006). А ЭЭГ нарушения в неонатальном периоде чаще представлены паттерном "вспышка-угнетение", в младенческом "гипсаритмией", а в раннем детском возрасте медленными генерализованными разрядами "спайк-волна". С возрастом ЭЭГ признаки эволюционируют с последовательным переходом одна в другую (S.Ohtahara1998, B.Карлов,2010)

Для всех эпилептических энцефалопатий характерно ослабление или даже прекращение дальнейшего прогрессирования в пубертатном возрасте, однако часто остается серьезный резидуальный нейрокогнитивный дефицит.

Выделяют следующие синдромы эпилептических энцефалопатий с дебютом в неонатальном, младенческом или раннем детском возрасте:

- синдром Драве (тяжелая миоклоническая эпилепсия младенчества)

- ранняя миоклоническая энцефалопатия

- эпилепсия с непрерывными спайк-волнами медленного сна

- гипоталамическая (геластическая) эпилепсия

- синдром Ландау-Клеффнера

- синдром Леннокса-Гасто

- миоклонический статус при непрогрессирующих энцефалопатиях

- синдром Отахара

- синдром Веста

Сравнительно недавно описаны новые формы детской эпилепсии, такие как злокачественные мигрирующие парциальные приступы младенчества - ЗМППМ (Coppola et al.1995, Veneselli et al.,2001), синдром Марканда-Блюме-Отахара - СМБО (младенческая эпилептическая энцефалопатия с множес- 
твенными, независимыми очаговыми спайками), а также атипичные микст-формы младенческих эпилептических энцефалопатий. Таксономическое положение описанных форм определено в группе эпилептических энцефалопатий (Ohtahara S., 2003), а также предлагается их рассматривать как мультифокальные формы эпилепсии с наличием так называемых "псевдогенерализованных" приступов (Мухин К.Ю.,2009,Лемешко И.,2011).

В мире описано не более ста пациентов из группы ЗМППМ и около 150 с СМБО (Coppola G. и соавт., 1995; Dulac O., 2005; Matsumoto A. и соавт., 2007). Однако реальные показатели, очевидно, выше приведенных значений из-за трудностей их распознавания в амбулаторно-поликлинических условиях, так как для диагностики требуется высокотехнологичное оборудование.

У детей с синдромами эпилептических энцефалопатий ,в основном, отмечается тяжелое течение заболевания, наблюдается грубая задержка психомоторного развития, высокий риск присоединения оппортунистических ин- фекций и высокий процент инвалидизации. Часто отмечается резистентность к проводимой антиэпилептической терапии (Dulac O., 2005).

В настоящее время недостаточно разработаны критерии диагностики, а возможности терапии очень ограничены. В результате пациенты не получают адекватную терапию, что, в свою очередь, дополнительно утяжеляет течение энцефалопатии. К сожалению, практические врачи часто не имеют возможности диагностировать также и доброкачественные эпилептические синдромы раннего и младенческого возраста.

Изучение форм детской эпилепсии, в том числе и сравнительно недавно выделенных группы синдромов эпилептических энцефалопатий (классификация 2001г), является актуальной проблемой эпилептологии. Тщательная оценка клинических, электрофизиологических и данных нейровизуализации определяет более точную диагностику, своевременную и наиболее рациональную терапию, что в конечном итоге, может значительно улучшить прогноз такого грозного заболевания, как эпилепсия.

\title{
XÜLASO
}

\section{EPILEPTIK ENSEFALOPATIYALARIN KLINIIKASI Və DİAQNOSTİKASI SUALLARINA DAİR}

\author{
N.N.Abasova, S.P.Өləkbərova, N.C.İsayeva \\ Azarbaycan Tibb Universiteti, nevrologiya vo tibbi genetika kafedrası, Bakı
}

Erkən uşaqlıq dövrü orqanizm strukturlarının və funksiyalarının, xüsusilə mərkəzi sinir sisteminin fasiləsiz inkişaf prosesi ilə səciyyələnir. Epileptik ensefalopatiyalar konsepsiyası baş beyninin inkişaf etməsi dövründə müşahidə olunan aqressiv epileptik fəallığın koqnitiv və neyropsixoloji pisləşmə və ya reqressin əsas səbəb faktorları olması fərziyyəsinə əsaslanır. Yaşla EEQ əlamətləri tədricən bir birinə keçməklə evolyusiya olunurlar. Hal hazırda diaqnostik meyarlar kifayət qədər müəyyən olunmayıb, terapevtik imkanlar isə məhduddur. Bunun nəticəsində pasiyentlər adekvat müalicə almırlar və bu, öz növbəsində, ensefalopatiyaların gedişini ağırlaşdırır. Təəssüf ki, praktiki həkimlər həmçinin erkən uşaqlıq və uşaqlıq dövrlərinin xoşxassəli epileptik sindromlarını da təyin etməkdə çətinlik çəkirlər. Kliniki, elektrofizioloji və neyrotəsviri müayinələrin nəticələrinin diqqətlə qiymətləndirilməsi daha dəqiq diaqnostikanı, vaxtlı və daha səmərəli terapiyanın təyin edilməsinə şərait yaradır. 


\title{
SUMMARY
}

\section{ON THE CLINICS AND DIAGNOSIS OF EPILEPTIC ENCEPHALOPATHY}

\author{
N.N.Abasova , S.P.Alekperova, N.J.Isayeva \\ Azerbaijan Medical University, department of neurology and medical genetics, Baku
}

Early childhood is characterized by a continuous process of development of structures and functions of organism, especially central nervous system.

The concept of epileptic encephalopathy is based on the assumption that the aggressive epileptic activity during the maturation of the brain is the main causal factor in cognitive and neuropsychological impairment or regress. With age, EEG signs of evolving consistent with the transition into each another. Currently the diagnosis criteria are not well developed and the treatment options are very limited, whereby patients cannot receive adequate treatment that further aggravates encephalopathy. Unfortunately clinicians are often unable to diagnose also benign epileptic syndromes. 